\title{
Coexistence of low-grade mucinous neoplasm and carcinoid (collision tumor) within multiple appendiceal diverticula: a case report
}

\author{
Neşe Ekinci' (D), Eylül Gün ${ }^{1}(\mathbb{D})$, Arzu Avcı' (D), Ahmet $\operatorname{Er}^{2}(\mathbb{D})$ \\ 1 Department of Pathology, Izmir Katip Çelebi University Atatürk Training and Research Hospital, İzmir, Turkey \\ ${ }^{2}$ Department of General Surgery, Izmir Katip Çelebi University Atatürk Training and Research Hospital, İmir, Turkey
}

\begin{abstract}
Neoplasms of the appendix are very rare. They usually show glandular or neuroendocrine differentiation, and when they both occur in the same area, it is called a "collision tumor." Low-grade mucinous neoplasms associated with appendiceal diverticula are also uncommon. The appendectomy specimen of a 60-year-old man contained dense and mucoid luminal content on the distal tip, and similarly a solid, yellow, lumen-obscuring tumor with a diameter of $1.5 \mathrm{~cm}$ at the base of the appendix was detected. Microscopically, there were three diverticula that comprised herniation of the mucosal layer through the appendiceal wall. Interestingly, all of the diverticula and the normal-appearing appendiceal wall were lined by adenomatous epithelium. The luminal portion had pools of mucin-containing, rare clusters of low-grade epithelium that gave rise to the diagnosis of a"low-grade mucinous neoplasm." The solid-appearing tumor was diagnosed as a "neuroendocrine neoplasm," and there was no transition zone between these two types of tumors. There are some cases that have been reported as low-grade mucinous neoplasms associated with appendicular diverticula and collision tumors consisting both mucinous neoplasms and carcinoid tumors in the literature; our case has a unique appearance with two different types of tumors both in the appendix wall and within multiple diverticula.
\end{abstract}

Keywords: Appendix, mucinous neoplasm, carcinoid, diverticuli

Cite this article as: Ekinci N, Gün E, Avcı A, Er A. ACoexistence of low-grade mucinous neoplasm and carcinoid (collision tumor) within multiple appendiceal diverticula: a case report. Turk J Surg 2021; 37 (3): 303-306.

Corresponding Author

Eylül Gün

E-mail: dreylulgun@gmail.com

Received: 24.04.2017

Accepted: 27.10 .2017

Available Online Date: 28.09 .2021

O Copyright 2021 by Turkish Surgical Society Available online at www.turkjsurg.com

DOI: 10.47717/turkjsurg.2021.3877

\section{INTRODUCTION}

Neoplasms of the appendix are rarely seen clinical entities, accounting for approximately $2 \%$ of all appendectomy specimens (1). They usually show glandular or neuroendocrine differentiation and sometimes may contain both cell types at once (2). The term "collision tumor" is used when both epithelial and neuroendocrine tumors are seen in the same area without juxtaposing on each other (3). Low-grade mucinous neoplasms associated with appendiceal diverticula are also uncommon (2). We report a case of a 60-year-old male with a concurrent low-grade mucinous neoplasm and carcinoid tumor both within the appendix and the appendiceal diverticula, the coexistence of which is unique.

\section{CASE REPORT}

A 60-year-old man presented with abdominal discomfort since 2 months and frequent pain in the right lower quadrant. His laboratory results were within normal limits except for mild anemia and a slight increase in the leukocyte count and carcinoembryonic antigen level. All tumor markers were negative. On physical examination, a palpable mass was identified in the right lower quadrant, and the appendix seemed cystically dilated in abdominal ultrasonography. With these findings and a suspected clinical diagnosis of mucocele, the patient underwent appendectomy. Written consent of the patient was obtained. On gross examination, the appendix measured $6.5 \mathrm{~cm}$ in length and $2 \mathrm{~cm}$ in diameter. The distal portion (tip) of the appendix contained dense and mucoid luminal content and seemed cystically dilated. The cut surface of appendiceal wall seemed irregular and had a thinned appearance with multiple outpouchings measuring 1-2 mm each (Figure 1). However, serial cuts toward the proximal portion revealed a solid, yellow, lumen-obscuring tumor with a diameter of $1.5 \mathrm{~cm}$ at the base of the ap- 


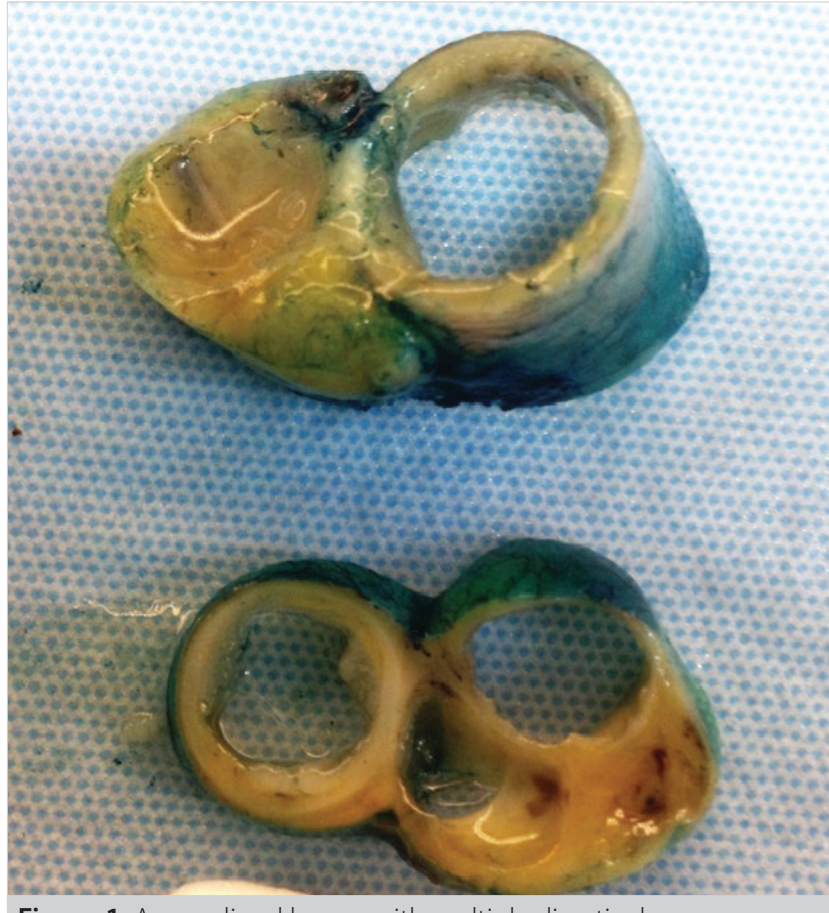

Figure 1. Appendiceal lumen with multiple diverticula.

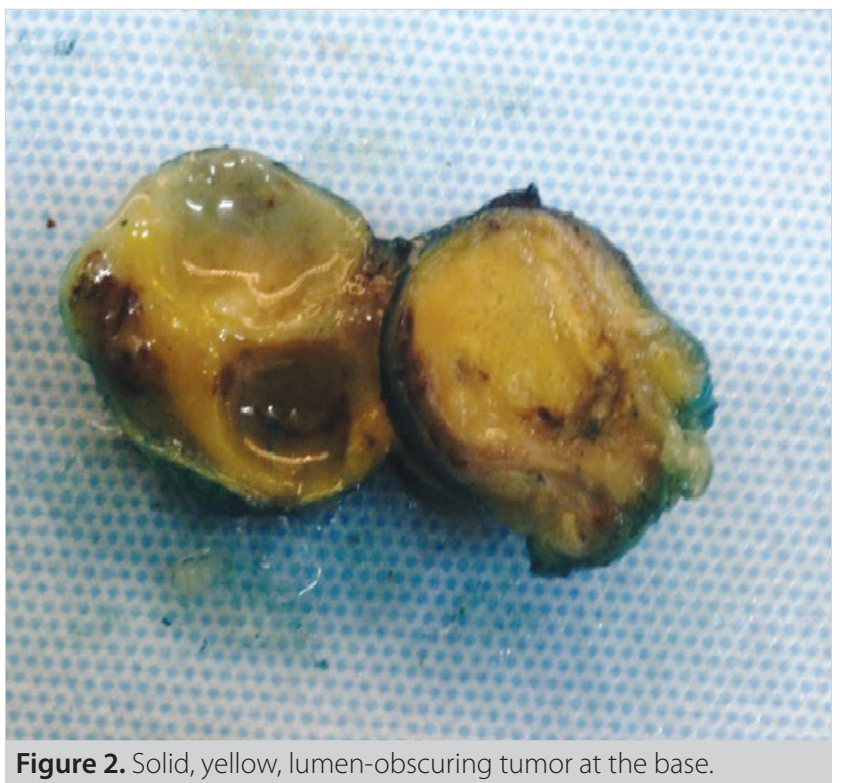

pendix (Figure 2). Microscopically, there were three diverticula measuring 2-3 $\mathrm{mm}$ that comprised herniation of the mucosal layer through the appendiceal wall. Interestingly, all of the diverticula and the normalappearing appendiceal wall were lined by adenomatous epithelium (Figure 3). This epithelium seemed pseudostratified and contained elongated, crowded columnar cells with hyperchromatic nuclei and showed acute inflammation within the stroma (Figure 4). The luminal portion had pools of mucin-containing, rare clusters of low-grade epithelium that gave rise to the diagnosis of a low-grade mucinous neoplasm.

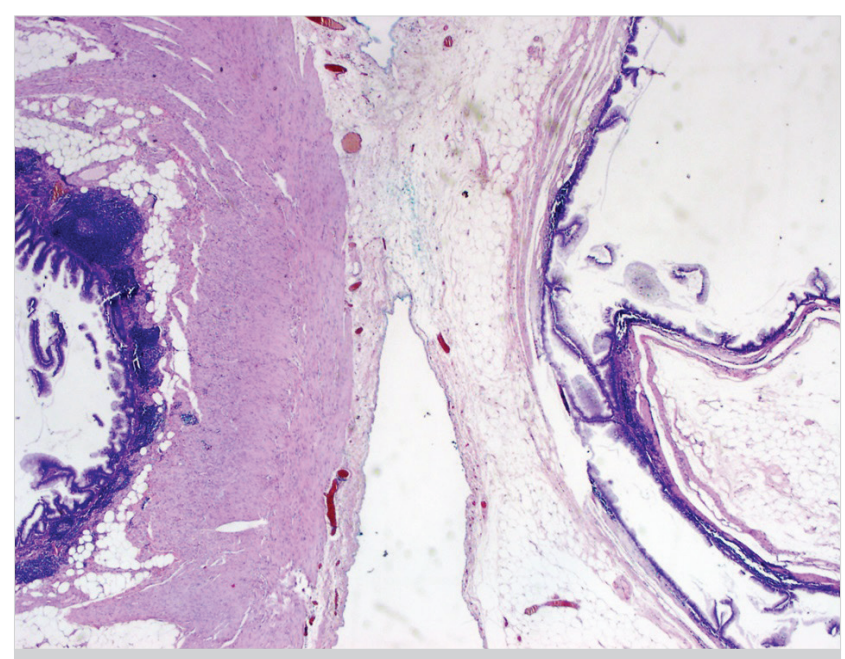

Figure 3. Appendiceal wall and diverticula lined by adenomatous epithelium.



Figure 4. Pseudo-stratification and hyperchromatic nuclei in the adenomatous epithelium.

Sections toward the proximal portion of the appendix showed another type of tumor with a solid appearance infiltrating the entire thickness of the appendiceal wall and the diverticula. It consisted of uniform tumor cells with no mitosis forming acini with nested and trabecular pattern, which was diagnosed as a neuroendocrine neoplasm of WHO Grade I (Figure 5). These cells were immunohistochemically positive for chromogranin A and synapt physin. Ki-67 index was lower than 1\%. There was no transition zone between these two types of tumors. The final diagnosis was a collision tumor of a low-grade mucinous neoplasm with carcinoid tumor both within the appendix and multiple appendiceal diverticula. The surgical department was informed and right hemicolectomy was suggested to the patient; however, he did not accept to have anothersurgery. On follow-up for 6 months after the operation, the patient was free of the disease. 


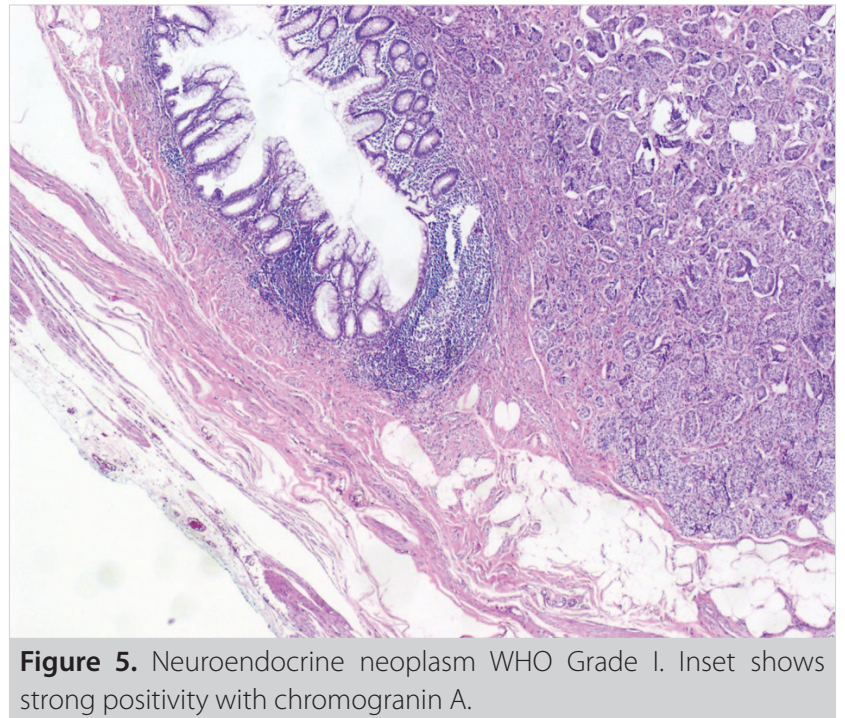

\section{DISCUSSION}

Low-grade mucinous neoplasms are rare in the appendix, comprising less than $1 \%$ of all appendiceal lesions; however, it is considered the most common cause of mucocele that is widely used as a clinical term to identify the lesions that produce mucin. Low-grade mucinous neoplasms are considered appendiceal counterparts of intestinal adenomatous lesions (46). Acquired diverticula are also uncommon and seen in $1 \%-2 \%$ of all appendiceal lesions. They have been widely investigated to understand the underlying mechanism of coexistence with appendiceal mucinous neoplasms (7). The coexistence of these two lesions has been reported by several authors and reported in approximately $30 \%-40 \%$ of cases with low-grade appendiceal neoplasms. However, it remains controversial whether they coexist by chance or there are other reasons in the pathogenesis that also give rise to ques tions about the formation of pseudomyxoma peritonei $(2,8)$. Carcinoid tumors are the most common appendiceal tumors, and they are usually found incidentally in appendectomies performed for acute appendicitis (1). The term collision tumor represents the condition when both the epithelial and carcinoid tumors are seen in the same area without any transitions in between. There are some controversial issues and hypothesis about the formation of these collision tumors; however, they are most likely believed to form independently from two different neoplasms as a result of biclonal malignant transformation (9). There are some cases that have been reported as low-grade mucinous neoplasms associated with appendicular diverticula and collision tumors consisting of both mucinous neoplasms and carcinoid tumors in the literature $(2,6,7,10)$. However, in our case, the entire appendiceal wall consisted of multiple appendiceal diverticula; in addition, there were two different types of tumors without any invasive foci and transition zone in between.
The surgical approach to carcinoid tumors and low-grade mucinous neoplasms is controversial. For carcinoids, the most recent guidelines indicate that a right hemicolectomy should be performed when the tumor size is $>2 \mathrm{~cm}$ and if there is lymph node metastasis, highgrade findings (high mitotic activity), and positive surgical margins (11). For mucinous appendiceal neoplasms (low-grade mucinous neoplasm in our case), the assessment should be made depending on the malignancy potential and the lymph node involvement of the lesion. However, because the initial operation is usually urgent, a mesenteric fat resection may not be performed in the first place, which leads to another controversial issue (12). The survival rates following right hemicolectomy compared with those following appendectomy have not been discussed clearly in the literature, and therefore more studies are needed in this context.

\section{CONCLUSION}

Collision tumors of the appendix are rare lesions. To the best of our knowledge, our case is the first with two different types of tumors both in the appendix wall itself and within multiple diverticula. Surgical approach to these tumors remains controversial and more clinical and prognostic studies are needed.

Peer-review: Externally peer-reviewed.

Author Contributions: Concept - N.E., E.G.; Design - N.E., E.G.; Supervision N.E.; Resource - N.E., E.G., A.E.; Materials - N.E., A.A., A.E.; Data Collection and/ or Processing - N.E., E.G.; Analysis and/or Interpretation - N.E., E.G.; Literature Search - E.G., A.A.; Writing Manuscript - E.G., N.E.; Critical Reviews - N.E., A.A., A.E.

Conflict of Interest: N The authors have no conflicts of interest to declare.

Financial Disclosure: The authors declared that this study has received no financial support.

\section{REFERENCES}

1. Chandrasegaram MD, Rothwell LA, An El, Miller RJ. Pathologies of the appendix: a 10-year review of 4670 appendicectomy specimens. ANZ J Surg 2012 Nov; 82(11): 844-7. [CrossRef]

2. Lamps LW, Gray GF Jr, Dilday BR, Washington MK. The coexistence of low-grade mucinous neoplasms of the appendix and appendiceal diverticula: a possible role in the pathogenesis of pseudomyxoma peritonei. Mod Pathol 2000 May; 13(5): 495-501. [CrossRef]

3. Singh NG, Mannan AASR, Kahvic M, Nur AM. Mixed adenocarcinoma-carcinoid (collision tumor) of the appendix. Med Princ Pract 2011; 20: 384-6. [CrossRef]

4. Bronzino P, Abbo L, Bagnasco F, Barisone P, Dezzani C, Genovese AM, et al. Appendiceal mucocele due to mucinous cystadenoma: case report and review of the literature. G Chir 2006 Mar; 27(3): 97-9. [CrossRef]

5. Yilmaz M, Akbulut S, Kutluturk K, Sahin N, Arabaci E, Ara C, et al. Unusual histopathological findings in appendectomy specimens from patients with suspected acute appendicitis. World I Gastroenterol 2013; 19(25): 4015-22. [CrossRef]

6. Al-Talib RK, Mason CH, Theaker JM. Combined goblet cell carcinoid and mucinous cystadenoma of the appendix. I Clin Pathol 1995; 48: 869-70. [CrossRef] 
7. Dupre MP, Jadavii I, Matshes E, Urbanski SJ. Diverticular disease of the vermiform appendix: a diagnostic clue to underlying appendiceal neoplasm. Hum Pathol 2008 Dec; 39(12): 1823-6. [CrossRef]

8. Ramaswamy V. Pathology of mucinous appendiceal tumors and pseudomyxoma peritonei. Indian J Surg Oncol 2016 Jun; 7(2): 258-67. [CrossRef]

9. Fukui H, Takada M, Chiba T, Kashiwagi R, Sakane M, Tabata F, et al. Concurrent occurrence of gastric adenocarcinoma and duodenal neuroendocrine cell carcinoma: a composite tumour or collision tumours? Gut 2001 Jun; 48(6): 853-6. [CrossRef]

10. Dellaportas D, Vlahos N, Polymeneas G, Gkiokas G, Dastamani C, Carvounis E, et al. Collision tumor of the appendix: mucinous cystadenoma and carcinoid. A case report. Chirurgia (Bucur) 2014 Nov-Dec 109(6): 843-5. [CrossRef]
11. Fornaro R, Frascio M, Sticchi C, De Salvo L, Stabilini C, Mandolfino $F$, et al. Appendectomy or right hemicolectomy in the treatment of appendiceal carcinoid tumors? Tumori 2007 Nov-Dec; 93(6): 587-90. [CrossRef]

12. Kehagias I, Zygomalas A, Markopoulos G, Papandreou T, Kraniotis P. Diagnosis and treatment of mucinous appendiceal neoplasm presented as acute appendicitis. Case Rep Oncol Med 2016; 2161952. [CrossRef]

\title{
OLGU SUNUMU-ÖZET
}

Turk J Surg 2021; 37 (3): 303-306

\section{Multipl apendiks divertikülünde düşük dereceli müsinöz neoplazm ve karsinoid (kollüz- yon tümör) birlikteliği: bir olgu sunumu}

\author{
Neşe Ekinci ${ }^{1}$, Eylül Gün ${ }^{1}$, Arzu Avcı ${ }^{1}$, Ahmet Er $^{2}$ \\ ${ }^{1}$ İzmir Katip Çelebi Üniversitesi Atatürk Eğitim ve Araştırma Hastanesi, Patoloji Anabilim Dalı, İzmir, Türkiye \\ ${ }^{2}$ Izmir Katip Çelebi Üniversitesi Atatürk Eğitim ve Araştırma Hastanesi, Genel Cerrahi Anabilim Dalı, Izmir, Türkiye
}

\section{ÖZET}

Apendiksin neoplazileri oldukça nadirdir. Genellikle glandüler ya da nöroendokrin diferansiyasyon gösterirler ve aynı alanda bir arada olduklarında "kollüzyon tümör" olarak adlandırılırlar. Apendiks düvertikülüyle birlikte olan düşük dereceli müsinöz neoplazmlar de oldukça nadirdir. 60 yaşında erkek hastanın appendektomi materyalinde kistik olarak dilatasyona uğramış distal kısımda yoğun, mukoid lümen içeriği izlendi. Benzer şekilde apendiks tabanında 1,5 cm çapında lümeni tıkayan solid, sarı-beyaz bir tümör görüldü. Mikroskopik olarak her biri apendisyel duvara mukozal tabakanın herniasyonuyla karakterli 3 adet divertikül izlendi. İlginç olarak, tüm divertiküller ve normal görünen apendiks duvarı adenamatöz epitelle döşeliydi. Lümende nadir düşük dereceli epitel fragmanları taşıyan müsin gölcüklerinin varlığı ile "düşük dereceli müsinöz neoplazm" tanısı kondu. Solid görünen tümör ise nöroendokrin neoplazi olarak değerlendirildi ve bu iki tip tümör arasında geçiş zonu izlenmedi. Literatürde apendiks divertikülüyle ilişkili düşük dereceli müsinöz neoplazm ve karsinoid tümörden oluşan kollüzyon tümörler bildirilmiştir ve bizim olgumuz hem apendiks duvarında hem de multipl divertikül içinde iki ayrı tümörün varlığı ile son derece ilginç bir birliktelik göstermektedir.

Anahtar Kelimeler: Apendiks, müsinöz neoplazi, karsinoid, divertikül

Doi: 10.47717/turkjsurg.2021.3877 